Victor Sales Pinheiro

Sol, Linha e Caverna: a dialética da imagem do bem na República de Platão

Dissertação de Mestrado

Dissertação apresentada como requisito parcial para obtenção do título de Mestre pelo Programa de PósGraduação em Filosofia da PUC-Rio.

Orientador: Profa. Maura Iglésias

Rio de Janeiro, dezembro de 2009 
Victor Sales Pinheiro

\title{
Sol, Linha e Caverna: a dialética da imagem do bem na República de Platão
}

\begin{abstract}
Dissertação apresentada como requisito parcial para obtenção do título de Mestre pelo Programa de PósGraduação em Filosofia da PUC-Rio. Aprovada pela Comissão Examinadora abaixo assinada.
\end{abstract}

Profa. Maura Iglésias

Orientador

Departamento de Filosofia da PUC - Rio

Profa. Maria Inês Sena Anachoreta Departamento de Filosofia da PUC - Rio

Prof. Fernando Augusto da Rocha Rodrigues UFRJ / IFCS

Prof. Marcus Reis Pinheiro UFF

Prof. Paulo Fernando Carneiro de Andrade Coordenador(a) Setorial do Centro de Teologia e Ciências Humanas PUC-Rio

Rio de Janeiro, 10 de dezembro de 2009 
Todos os direitos reservados. É proibida a reprodução total ou parcial do trabalho sem autorização da universidade, do autor e do orientador.

\section{Victor Sales Pinheiro}

Graduou-se em Direito pelo Centro Universitário do Pará, em 2007. Participou de diversos congressos no país, nas áreas de Filosofia Antiga e Hermenêutica. É coordenador, junto com Benedito Nunes, da edição bilíngüe da obra de Platão, traduzida por Carlos Alberto Nunes e editada pela Editora da Universidade Federal do Pará.

Ficha Catalográfica

Pinheiro, Victor Sales

Sol, linha e caverna: a dialética da imagem do bem na República de Platão / Victor Sales Pinheiro ; orientador: Maura Iglésias. - 2009.

131 f. ; $30 \mathrm{~cm}$

Dissertação (Mestrado em Filosofia)-Pontifícia Universidade Católica do Rio de Janeiro, Rio de Janeiro, 2009.

Inclui bibliografia

1. Filosofia - Teses. 2. Platão. 3. República. 4. Idéia do bem. 5. Dialética. 6. Imagens. I. Iglésias, Maura . II. Pontifícia Universidade Católica do Rio de Janeiro. Departamento de Filosofia. III. Título. 


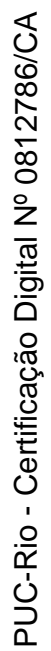

À Eva Andersen Pinheiro, minha luz. 


\section{Agradecimentos}

Ao CNPq e à PUC, pelas bolsas de estudos concedidas.

Aos professores Maura Iglésias, Fernando Rodrigues, Maria Inês Anachoreta e Marcus Reis pela atenção concedida na leitura e avaliação deste trabalho.

À minha família, minha fortaleza, meus pais Pedro e Nena, e meu irmão Pedro Neto, pelo apoio e confiança incondicionais. Não há nada meu que não seja também deles, e esta unidade é o núcleo da minha felicidade, o fundamento de qualquer passo que eu possa dar.

À minha "família carioca", Sérgio, Maria Lúcia e Serginho, pelo carinho e atenção constantes.

Certas amizades concederam ao meu percurso intelectual no Rio uma forte carga afetiva. Registro minha gratidão a Tom (Alexandre Costa), Remo Mannarino, Rafel Huguenin, Luiz Otávio Mantovanelli, Marcelo Rangel e Marco Antonio Casanova. Mais do que interlocutores, testemunham que filosofia não se faz sem amor partilhado ao saber.

Aos colegas da PUC, pelo companheirismo: Antonio Queiróz, Paulo Melo, Christina Ribas, Kátia Frecheiras e Renato Mattoso.

Aos amigos, sempre presentes, Angélica Nancy, Pedro Araújo, Adriano Bastos, Nayara e Bruno Guedes, Liv Sarmento, Benjamim Hamoy, Ney Gomes, David Carneiro, Bernardo Mendes e Evinha Pinheiro, pelo constante apoio aos meus estudos.

Ao meu amigo pe. Fabrizio Meroni, primeiro entusiasta dos meus estudos de filosofia grega.

Ao meu amigo e mestre Benedito Nunes, exemplo máximo de vida filosófica.

À Laíse Araújo, pela mais profunda intimidade e mais perfeita cumplicidade, que acompanhou, vibrante, cada passo deste estudo, animando-o com a verdade do amor. 


\section{Resumo}

Pinheiro, Victor Sales; Iglésias, Maura. Sol, linha e caverna: a dialética da imagem do bem na República de Platão. Rio de Janeiro, 2009. 131 p. Dissertação de Mestrado - Departamento de Filosofia, Pontifícia Universidade Católica do Rio de Janeiro.

Esta dissertação examina a idéia do bem na República de Platão, nas famosas imagens do Sol (505a-509b), da Linha (509d-511e) e da Caverna (514a521b; 531c-535a). Após uma introdução que justifica a importância do tema e traz as hipóteses centrais deste estudo, é descrito o contexto em que é apresentada a idéia do bem, como fundamento da principal proposição do diálogo, o governo dos filósofos. No capítulo seguinte, o terceiro, é analisado o uso de imagens, didaticamente conduzido por Sócrates a fim de convencer seus interlocutores da necessidade deste conhecimento máximo e do modo de conhecê-lo, a dialética que renuncia às imagens. Neste capítulo terceiro, são estudadas, ainda, a metáfora e a analogia, relacionadas à teoria das idéias, a fim de entender o aparente paradoxo de condenar as imagens usando-as. O objetivo do quarto capítulo é entender a analogia do Sol, que representa a função causal do bem e indica a sua condição ontológica e epistemológica, além do ser e da essência. O quinto capítulo estuda a imagem da Linha, a fim de identificar a posição do bem, como princípio não hipotético de tudo, na estrutura geral da realidade, indicando o estado da alma que o conhece, a noesis. O sexto capítulo estuda a alegoria da Caverna, seu aspecto pedagógico e a forma de conhecimento dialético capaz de alcançar a idéia do bem, demonstrando a conseqüência prática, ética e política, deste saber.

\section{Palavras-chave}

Platão; República; Idéia do bem; Dialética; Imagens. 


\section{Abstract}

Pinheiro, Victor Sales; Iglésias, Maura (advisor). Sun, Line and Cave: the dialectics of the image of the good in the Republic of Plato. Rio de Janeiro, 2009. 131 p. MSc Dissertation - Departamento de Filosofia, Pontifícia Universidade Católica do Rio de Janeiro.

This dissertation examines the idea of the good in the Republic of Plato, in the famous images of the sun (505a-509b), the line (509d-511e) and the cave (514a-521b; 531c-535a). After an introduction that justifies the importance of the subject and brings the central hypothesis of this study, it is described the context in which it is presented the idea of the good, as the fundament of the capital proposition of the dialogue, the philosophers' government. In the following chapter, the third one, it is analyzed the use of images, conducted by Socrates to convince his interlocutors of the necessity of this maximum knowledge and the way of knowing it, the dialects that renounce images. In this third chapter, it is yet studied the metaphor and the analogy related to the theory of ideas, to understand the apparent paradox of condemning images using them. The aim of the fourth chapter is to comprehend the analogy of the sun, which represents the causal function of the good and indicates its ontological and epistemological condition, beyond being and essence. The fifth chapter studies the image of the line, to identify the position of the good, as the non hypothetical first principle of everything, in the general structure of reality, indicating the state of soul that knows it, the noesis. The sixth chapter studies the allegory of the cave, its pedagogical aspect and the form of dialectical knowledge able to achieve the idea of the good, demonstrating the practical consequence, ethical and political, of this knowledge.

\section{Palavras-chave}

Plato; Republic; Idea of the good; Dialectics; Images 


\section{Sumário}

1- Introdução 9

2- Do esboço à obra completa: quando e por que surge a idéia do bem 15

3- O uso didático de imagens 22

3.1) Da relutância à opinião 22

3.2) Doxa e imagem 25

3.3) Imagem e Analogia 27

3.4) O método metafórico de uma metodologia metafísica 30

3.5) A finalidade didática das analogias 31

3.6) Didática metafórica e teoria das idéias: do sensível ao inteligível 33

4- O Sol, a função do bem (505a-509b) 36

4.1) A causalidade prática do bem: o sentido de agathos 36

4.2) O bem como idéia 41

4.3) O saber do filósofo: a necessidade de um modelo perfeito, perfeitamente conhecido 44

4.4) Visão e Geração: as funções causais da idéia do bem 47

4.5) O estatuto onto-epistemológico da idéia do bem 53

5- A Linha, o lugar do bem (509d-511e) 61

5.1) O desenvolvimento da metáfora solar $\quad 61$

5.2) A clareza da verdade: o realismo ontológico de Platão 62

5.3) O domínio do inteligível: dianoia e noesis 66

5.4) A idéia do bem como anhipotético $\quad 79$

6- A Caverna, a dialética do bem (514a-521b; 531c-535 $)$

6.1) A Caverna na seqüência do Sol e da Linha 87

6.2) A função da Caverna: educação e conversão 92

6.3) A dialética e o bem 96

6.4) O valor da verdade e a verdade do valor: a orientação ético-política
da idéia do bem

$\begin{array}{ll}\text { 7- Conclusão } & 120\end{array}$

8- Bibliografia $\quad 124$

8.1) Edições e traduções da República 124

8.2) Demais livros e artigos 125 